\title{
Motivacija za rad i izgaranje učitelja informatike, tehničke kulture i strukovnih predmeta
}

\author{
Ivica Boljat \\ Prirodoslovno-matematički fakultet \\ Sveučilište u Splitu \\ Split, R. Boškovića 33 \\ boljat@pmfst.hr
}

\begin{abstract}
Sažetak
Provedeno je istraživanje na uzorku od 2829 učitelja osnovnih i nastavnika srednjih škola iz svih hrvatskih županija s ciljem otkrivanja njihove percepcije radnih uvjeta kao potencijalnih stresora i njihovoj povezanosti s motivacijom za rad, simptomima izgaranja i namjerom za napuštanje posla. Anketom su ispitani stavovi učitelja potaknuti Skaalvikovim istraživanjima. Faktorskom analizom dobiveni su vrlo slični rezultati. Dodana su i pitanja o opterećenju učitelja u online nastavi uzrokovanoj COVOD-19 pandemijom, o pritisku na samostalnost učitelja od strane ravnatelja i roditelja te o društvenom statusu učitelja. U radu se stavlja naglasak na analizu rezultata koji se odnose na 504 učitelja i nastavnika informatike, tehničke kulture i srodnih strukovnih predmeta. Pokazale su se razlike u stavovima s obzirom na spol, godine staža, razinu škole u kojoj su zaposleni, vrstu studija kojeg su završili te napredovanje učitelja. Kvalitativnom analizom komentara učitelja detektirali su se glavni izvori nezadovoljstva iz perspektive učitelja, kao i potpora ovakvim istraživanjima i nada da će rezultati utjecati na promjenu odnosa Ministarstva prema učiteljima.
\end{abstract}

Ključne riječi: motivacija učitelja; stres učitelja; izgaranje učitelja; zadovoljstvo poslom; zahtjevi posla.

\section{Uvod}

Istraživanja u više država pokazuju da stres i simptomi izgaranja pogađaju sve više učitelja koji sve češće razmišljaju o napuštanju učiteljskog poziva (Skaalvik \& Skaalvik, 2015). Povećani stres dovodi do manjeg zadovoljstva poslom, smanjene predanosti i procjene vlastite efikasnosti poučavanja, simptoma izgaranja te napuštanja profesije. S druge strane, zadovoljstvo poslom glavni je prediktor manje razine iscrpljenosti i napuštanja poziva. I stres i zadovoljstvo poslom značajno ovise o organizacijskim i socijalnim elementima radnog okružja i zahtjevima posla (Demerouti, 2001).

Više aspekata učiteljskog posla, tzv. stresora, poput vremenskog pritiska i opterećenja na poslu, disciplinskih problema, gubitka autonomije, sukoba $s$ upravom i roditeljima može dovesti do pojave neugodnih emocija, odnosno stresa. Stres karakterizira emocionalna iscrpljenost (niska energija i trajni umor), depersonalizacija (negativan odnos prema učenicima i kolegama) te osjećaj da ne rade smislen i važan posao (Maslach, 1996). U ovom radu koriste se dva pristupa za detekciju i mjerenje potencijalnih stresora: unaprijed je definirana većina kategorija pitanja za pretpostavljene stresore i učitelji trebaju procijeniti u kojoj mjeri su relevantni, ali se iz slobodnih komentara učitelja mogu nazrijeti i novi, prije svega nezadovoljstvo odnosom i komunikacijom Ministarstva znanosti i obrazovanja prema učiteljima te povlaštenom položaju roditelja koje im Ministarstvo osigurava. Dvije skupine varijabli vezanih 
za školski kontekst mogu djelovati na stres: zahtjevi posla mogu provocirati psihološke i fiziološke probleme, dok s druge strane neki organizacijski i društveni resursi ublažavaju te posljedice i omogućuju veće zadovoljstvo i osobni rast učitelja. One nisu nezavisne već međusobno interagiraju pa su tako najzadovoljniji učitelji više angažirani i samim tim više izloženi opasnosti izgaranja.

Te su varijable temelj za JD-R (Job DemandsResources) (Demerouti, 2001) model prema kojem su definirane skupine pitanja u ovom istraživanju. Nedostatak modela je što neke varijable poput odnosa s kolegama i autonomija mogu biti i stresori i potpora u povećanju zadovoljstva, ovisno o okolnostima.

\section{Motivacija za posao i stres učitelja}

Razlozi ili motivi za odabir učiteljskog zanimanja mogu se svrstati u tri osnovne kategorije: altruistični motivi (rad s djecom, pomoć djeci u njihovom uspjehu i razvoju, želja da se pridonese dobrobiti društva), intrinzični razlozi (interes za prenošenje specifičnog znanja) i ekstrinzični razlozi (dugi praznici, sigurne plaće ili društveni status) (Beck, 2003). Teorije motivacije za rad zaposlenike gledaju kao socijalna bića, kao ekonomska bića motivirana isključivo ekonomskim razlozima kojima se manipulira plaćama i nagradama ili kao samoaktualizirajuća bića koja se ponose svojim radom, rad im pruža mogućnost napredovanja i razvoja, a neki aspekti posla dopuštaju ljudima da zadovolje „potrebe višeg reda“. Potrebno im je priznanje, osjećaj postignuća, druženje, izazov, ugled, poticajnost. Odsutnost nekih elemenata dovodi do nezadovoljstva a ono do sniženja produktivnosti. Maslowljeva teorija hijerarhije potreba pojašnjava stupnjevanje potreba od temeljnih bioloških do najviših psiholoških. Vroomova teorija pretpostavlja očekivanje da uloženi napor ili zalaganje na radu mogu dovesti do određene razine postignuća, pri čemu će to postignuće biti instrumental za ostvarenje nekog dugoročnog cilja. Teorija pravednosti pretpostavlja da čovjek uspoređuje intenzitet svog posla s onim što dobiva za uzvrat i ako opaža nerazmjer, to ga čini nezadovoljnim.

Često se čuje da je učiteljsko zanimanje jedno od stresnijih zanimanja te da je sve manje zainteresiranih mladih ljudi koji žele postati učitelji. Promjene $u$ načinu odgoja djece, brži stil života, veća zaposlenost roditelja te općenito sve veći zahtjevi učiteljskog zanimanja stavljaju učitelje pred nove izazove. Od nastavnika se očekuje da postavljaju interese svojih učenika iznad svojih, što može generirati situacije iz kojih nekad proizlazi zadovoljstvo, a nekad napetosti, sukobi i svađe (Mađarac, 2018). Poslovni zahtjevi, posebno nedostatak vremena, snažno predviđaju nedostatak dobrobiti, dok percipirani poslovni resursi uključeni $u$ istraživanje umjereno predviđaju više razine dobrobiti. Analiza je otkrila da žene percipiraju poslovne resurse pozitivnije od svojih muških kolega (Skaalvik \& Skaalvik, 2018)

Postoji pozitivna veza učiteljske samoučinkovitosti i autonomije $s$ angažmanom i osobnim zadovoljstvom učiteljskim zanimanjem, dok emocionalna iscrpljenost značajno negativno korelira sa samoučinkovitosti. Autonomija podrazumijeva da se od učitelja ne očekuje da koristite metode poučavanja koje im nisu ugodne ili zahtijevaju više vremena za pripremu. Učitelji sa snažnim očekivanjima mogu autonomiju doživljavati kao dobru priliku za poučavanje prema vlastitim vrijednostima, kako bi koristili svoje resurse, eksperimentirali s novim načinima i mijenjali načine ovisno o situaciji i potrebama učenika. Za učitelje s niskim očekivanjima, autonomija može pružiti priliku za skrivanje osobnih nedostataka, ne može biti korisna za učenje i njihov razvoj kao nastavnika (Skaalvik \& Skaalvik, 2014). Učitelji iz prakse pokazuju veću samoučinkovitost i veći stres, manje su predani profesiji i skloniji su odustajanju od zaposlenih na stručnom osposobljavanju (Klassen \& Chiu, 2011). Učitelji iz osnovnih škola imaju veću samoučinkovitost u odnosu na srednjoškolske nastavnike, muškarci su bolji za $5 \%$. Ona raste s godinama iskustva, a od sredine radnog vijeka će početi lagano padati. Kako bi učitelji u kasnijim fazama svoje karijere bili učinkovitiji, potrebni su programi stručnog usavršavanja koji mogu poboljšati vještine, znanja i samopouzdanje (Klassen \& Chiu, 2010). Različite vrste potpore trebat će i nakon odslušanog profesionalnog razvoja radi učinkovitog provođenja svega što su naučili (Osman \& Warner, 2020).

Emocionalna iscrpljenost i depersonalizacija pokazale su značajnu povezanost sa svim faktorima stresa vezanim za posao (Kokkinos, 2007). Udane su učiteljice iscrpljenije od oženjenih učitelja. Kontrola neposluha učenika i nedostatak vremena značajno pojačavaju izgaranje nastavnika, a ocjenjivanje učitelja od strane učenika te nedostatak vremena značajno pojačavaju neurotičnost. Učitelji koji su ocijenjeni niskim ocjenama pokazat će viši stupanj depersonalizacije. Učitelji koji su bezvoljni, neodlučni te nedovoljno uporni u ostvarenju svojih ciljeva vjerojatno će pokazati bezobrazluk, cinizam i distanciranost od svojih učenika kako bi izbjegli stres. Unapređenje vještina učitelja u upravljanju razredom moglo bi značajno unaprijediti sustav obrazovanja. Istraživanje u Hong Kongu (Ho, 2015) pokazalo je da pojedinci koji se često šale $s$ drugima i održavaju veselu perspektivu života imaju niže razine emocionalne iscrpljenosti i depersonalizacije te postižu bolje osjećaje osobnog postignuća.

Prevelik broj učenika jedan je od faktora koji može otežati rad učitelja (Boru, 2018), kao i nedovoljna 
stručnost učitelja za nošenje s problemima učenika s posebnim potrebama (Skaalvik \& Skaalvik, 2015).

Sargent i Hannum (2005) pokazali su da je prosječna plaća seoskih učitelja u Kini koji su svoju profesiju predstavili kao idealnu bila manja od prosječne plaće učitelja kojima to nije idealna profesija što se može objasniti motivacijskom teorijom spoznajnog nesklada. Učitelji će vrlo vjerojatno napustiti svoju profesiju ako smatraju da u selu postoje unosniji poslovi, što dovodi do problema zadržavanja kvalificiranih učitelja u siromašnim sredinama. Učitelji koji žele poboljšati karijeru žive $u$ bogatijim selima od učitelja koji nemaju takve ciljeve. Mlađi učitelji su nezadovoljniji nego stariji, žene su zadovoljnije svojom profesijom od muškaraca. Učitelji koji se uz redovan posao bave poljoprivredom bili su zadovoljniji od ostalih.

Premda kao izvor stresa učitelji navode nedovoljnu uključenost u proces odlučivanja u školi, njihova uključenost $u$ donošenje odluka nekad izaziva još više sukoba s upravom pa opet nastupa stres. U norveškim školama učitelji zajedno surađuju i planiraju plan i program rada. Najmlađi nastavnici imaju podršku i uče od drugih kolega, te se svi međusobno pomažu. lako je timski rad opisan kao izvor uživanja i zadovoljstva na poslu, pokazalo se i da on može predstavljati izazov i izazvati stres. Timski rad često dovodi do nesuglasica pa čak i otvorenih svađa pred učenicima (Skaalvik \& Skaalvik, 2015).

Stres kod srednjoškolskih nastavnika u Ekvadoru (Vazquez-Cano \& Holgueras-Gonzalez, 2019) uzrokuju verbalna agresija učenika, nedostatak podrške školske uprave, održavanje predavanja iz predmeta koji nisu njihova struka, pritisak škole za postizanje dobrih rezultata, nedostatak sudjelovanja u odlukama, rivalstvo među kolegama učiteljima. Danas je moguće očekivati da se verbalne agresije lako mogu proširiti na društvene mreže i digitalni svijet, što može prouzrokovati ozbiljne psihološke posljedice i nedostatak radnog ugleda. Često objavljivanje rangiranja škola također je jedan od faktora koji izazivaju veliki stres i pritisak na učitelje. Nedostatak podrške kolega ili školske uprave je isto jedan od mogućih aktivatora stresa. Loši uvjeti rada i buduća perspektiva faktor je koji najbolje opisuje stres učitelja. Stres nije ograničen samo na socijalnoprofesionalne čimbenike, već je i pod utjecajem obiteljskih i osobnih pitanja koja se reflektiraju na rad nastavnika.

Sve glasnije su primjedbe učitelja da su izloženi velikom stresu $\mathrm{u}$ svom radu od strane roditelja (Anastasiou \& Papagianni, 2020). Dok roditelji daju visoki prioritet njihovom uključivanju u obrazovna pitanja i sudjelovanju u odlučivanju, učitelji se tome opiru, a podržavaju roditeljsku uključenost u vezi s mjesečnim školskim sastancima, informiranosti o akademskom uspjehu njihove djece te o tehničkim ili financijskim pitanjima. Razrednici često imaju problema s roditeljima koji previše dolaze u školu jer očekuju da se razrednik brine o svemu, ali i s onim roditeljima koji nikad ne dolaze u školu.

\section{Istraživanje}

Istraživanje je potaknuto sličnim istraživanjem provedenim u norveškim srednjim školama (Skaalvik \& Skaalvik, 2017) a za cilj je imalo utvrditi stavove hrvatskih učitelja informatike, tehničke kulture i srodnih strukovnih predmeta o zahtjevima učiteljskog posla kao potencijalnim stresorima te organizacijskim i društvenim poslovnim resursima. Istražio se i njihov utjecaj na samoprocjenu učinkovitosti učitelja, simptome izgaranja, zadovoljstvo poslom i motiviranost učitelja za daljnji rad.

$\mathrm{U}$ odnosu na uobičajene pitanja u istraživanjima ove problematike, dodane su i kategorije pitanja o opterećenju učitelja $u$ online nastavi uzrokovanoj COVOD-19 pandemijom, o pritisku na samostalnost učitelja od strane ravnatelja i roditelja te o društvenom statusu učitelja. Utvrdile su se i razlike $s$ obzirom na spol, godine radnog iskustva $u$ obrazovanju, razinu škole zaposlenja, vrstu završenog studija te napredovanja u zvanju učitelja. Kvalitativnom analizom komentara učitelja detektirali su se glavni izvori nezadovoljstva iz perspektive učitelja, kao i potpora ovakvim istraživanjima i nada da će rezultati utjecati na promjenu odnosa Ministarstva prema učiteljima. Glavnina popunjenih anketnih upitnika pristigla je u drugoj polovini lipnja 2020.

\section{Metode}

\subsection{Sudionici i procedura izbora}

Elektroničkom poštom u lipnju 2020. poslani su upitnici na adrese gotovo 20000 učitelja osnovnih i nastavnika srednjih škola iz svih hrvatskih županija koji su sudjelovali u edukaciji u organizaciji Ministarstva odgoja i obrazovanja povodom uvođenja „Škole za život“. Upitnike je dragovoljno popunilo 2829 sudionika istraživanja, od toga 504 učitelja informatike, tehničke kulture i srodnih stručnih predmeta. Odziv se može smatrati vrlo velikim jer je istraživanje bilo u jako nezgodnom vremenu završetka školske godine koja je bila po mnogo čemu stresna i u vrijeme inflacije raznih anketa, često obveznih.

Strukturu ispitanika prikazuje slika 1 te tablice $1 \mathrm{i}$ 2. 


\section{Predmeti koje predaju}

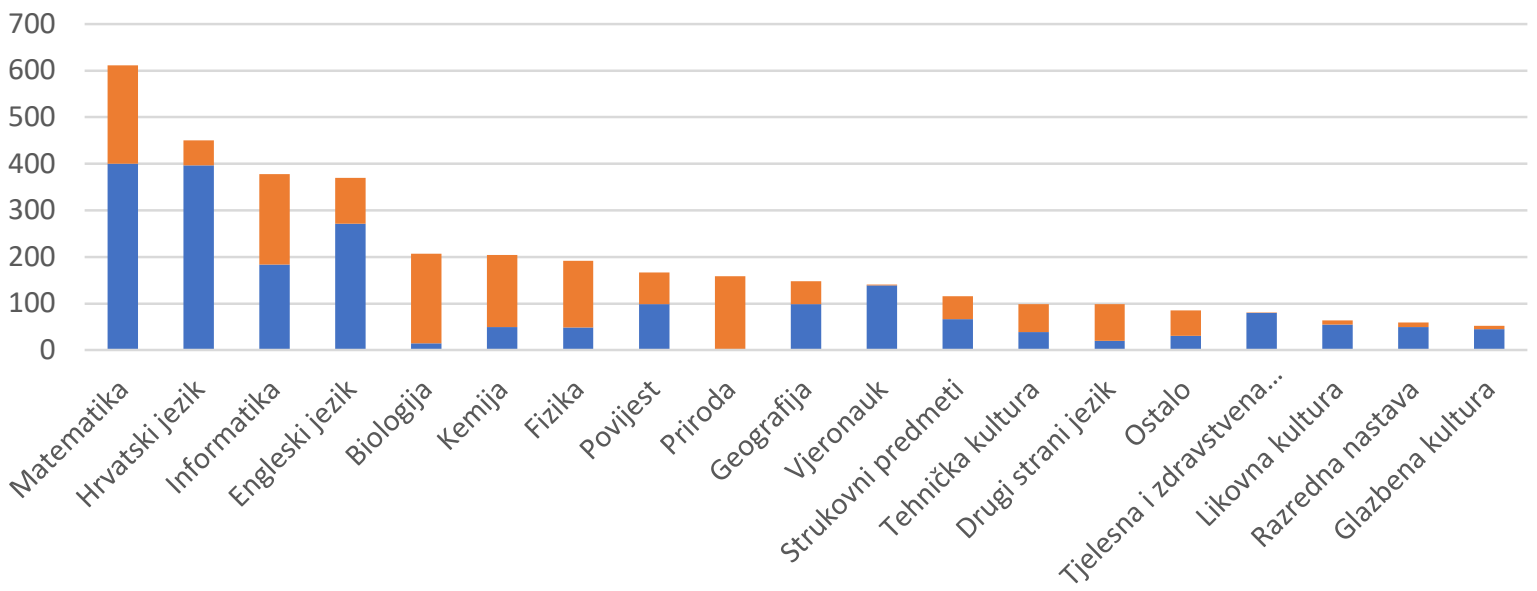

- Predaju samo jedan predmet $\quad$ Predaju više predmeta

Slika 1: Struktura sudionika istraživanja prema predmetima koje učitelji predaju

\begin{tabular}{|c|c|c|c|c|c|c|c|c|}
\hline & \multicolumn{2}{|c|}{ Spol } & \multicolumn{3}{c|}{ Škola zaposlenja } & \multicolumn{3}{c|}{ Završen studij } \\
\hline & muški & ženski & osnovna & srednja & $\begin{array}{c}\text { OŠ i } \\
\text { SŠ }\end{array}$ & nastavnički & $\begin{array}{c}\text { drugi + } \\
\text { pedagoške }\end{array}$ & $\begin{array}{c}\text { drugi bez } \\
\text { pedagoških }\end{array}$ \\
\hline Svi učitelji & 395 & 2434 & 1832 & 911 & 86 & 2378 & 440 & 11 \\
\hline INF, TK, Strukovni & 125 & 379 & 297 & 194 & 13 & 286 & 215 & 3 \\
\hline
\end{tabular}

Tablica 1. Struktura sudionika prema spolu, školi zaposlenja i završenom studiju

\begin{tabular}{|c|c|c|c|c|c|c|c|c|}
\hline & \multicolumn{4}{|c|}{ Radno iskustvo u obrazovanju } & \multicolumn{4}{c|}{ Napredovanje u zvanju } \\
\hline & $\begin{array}{c}0-5 \\
\text { god }\end{array}$ & $\begin{array}{c}6-15 \\
\text { god }\end{array}$ & $\begin{array}{c}16-30 \\
\text { god }\end{array}$ & $\begin{array}{c}31-40 \\
\text { god }\end{array}$ & $\begin{array}{c}\text { bez } \\
\text { napred. }\end{array}$ & Mentor & savjetnik & $\begin{array}{c}\text { voditelj } \\
\text { ŽSV i sl. }\end{array}$ \\
\hline Svi učitelji & 403 & 879 & 1231 & 316 & 2050 & 435 & 377 & 7 \\
\hline INF, TK, Strukovni & 96 & 164 & 199 & 45 & 337 & 88 & 76 & 3 \\
\hline
\end{tabular}

Tablica 2. Struktura sudionika prema radnom iskustvu i napredovanju u zvanju

\subsection{Mjerni instrument}

Korišten je anketni upitnik kojeg su učitelji zaprimili putem elektroničke pošte i dobrovoljno ga ispunili. Ponuđeni odgovori na sva pitanja su prema Likertovoj skali od 1: „U potpunosti se ne slažem“ do 6: „U potpunosti se slažem", osim za autonomiju u radu (15). Pitanja su grupirana u nekoliko kategorija prema (Skaalvik \& Skaalvik, 2017), a dodatne kategorije pitanja označena su zvjezdicom:

Osobna karakteristika učitelja obuhvaća 8 općih pitanja: spol, škola u kojoj rade, županija, godine staža, godine života, vrsta studija kojeg su završili, predmeti koje predaju, napredovanje u zvanju.

Zahtjevi posla: nedostatak vremena, odnosno preveliko radno opterećenje (5 pitanja) s dodatnim opterećenjem zbog online nastave* (3 pitanja), problemi s disciplinom učenika ( 2 pitanja), pritisak na samostalnost učitelja* (3 pitanja) i niska motiviranost učenika (4 pitanja).

Poslovni resursi: jedan organizacijski - autonomija učitelja (6 pitanja) te tri socijalna resursa - odnos $\mathrm{s}$ kolegama (3 pitanja), podrška školske uprave (3 pitanja) te kolektivna školska kultura (3 pitanja). 
Zavisne varijable: samoprocjena učinkovitosti učitelja (5 pitanja), društveni status i poštovanje od strane

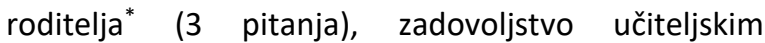
zanimanjem (4 pitanja) i namjera za napuštanje učiteljskog poziva (4 pitanja).

\subsection{Analiza podataka}

Unutarnja povezanost pitanja upitnika, odnosno mjera pouzdanosti instrumenta (Cronbach'a Alpha) iznosi 0.807 za sve učitelje, odnosno 0.834 za učitelje informatike, tehničke kulture i strukovnih predmeta. Također, u svrhu provjere kontekstualne valjanosti dobivene su visoke unutarnje povezanosti pitanja svake kategorije upitnika u rasponu od 0.813 do 0.931 , a kod dodatnih pitanja 0.705 do 0.749 .

$U$ radu se detaljno analiziraju podaci koji se odnose na 504 učitelja informatike, tehničke kulture i srodnih strukovnih predmeta. Analizirane su frekvencije odgovora svih pitanja, aritmetičke sredine i medijani. Istražene su razlike prema spolu, godinama radnog iskustva u obrazovanju, školi zaposlenja, završenom studiju te napredovanju učitelja neparametrijskim statističkim metodama Mann-Whitney i KruskalWallis, jer promatrani podaci nisu zadovoljili uvjet normalne raspodjele.

Primjenom faktorske analize napravljena je komparativna analiza izlučenih faktora, njihove strukture i unutarnje konzistentnosti te doprinosa ukupnoj varijanci s rezultatima Skaalvikovog istraživanja (Skaalvik \& Skaalvik, 2017) u norveškim srednjim školama. Dodatna analiza strukturnim modeliranjem (SEM) za sada nije napravljena.

U svim statističkim obradama i analizama korišten je programski paket SPSS 24.

\section{Rezultati}

\subsection{Deskriptivna statistika}

Za svaku od 12 kategoriju pitanja navodi se prosječna vrijednost na Likertovoj skali te ukupni postotak odgovora "5" i "6" koji označavaju jako i vrlo jako slaganje s navedenim izjavama:

Rješavanje disciplinskih problema u radu $s$ učenicima: Učitelji smatraju da problemi u ponašanju nekih učenika značajno otežavaju održavanje nastave (prosjek 4.3 na Likertovoj skali 1-6, postotak odgovora u kategorijama "5“ i "6“ iznosi 50\%) te da njihovo rješavanje oduzima puno vremena i energije (4.3 / 48.2\%).

Nedostatak vremena: Učitelji su pretrpani poslom (4.9 / 69.3\%), svoje slobodno vrijeme često koriste pripremajući se za nastavu (5.2 / 78.4\%), nemaju vremena za odmor i oporavak (4.4 / 52.2\%). Sastanci, administrativni poslovi i dokumentacija oduzimaju im puno vremena $(5,0 / 72.2 \%)$, nauštrb vremena koje provode s učenicima (5.1 / 75\%).

Motivacija učenika za učenje: Učitelji za mnoge svoje učenike smatraju da pokazuju malo interesa za školske aktivnosti (3.9 / 35.5\%) i da odustaju čim se sretnu s prvim problemom (4.0 / 43.3\%). Teško ih je zainteresirati za ozbiljniji rad u školi (4.0 / 39.1\%), a pri izvršavanju školskih aktivnosti ne ulažu dovoljno truda (4.3 / 49\%).

Odnosi s kolegama i upravom škole: Odnos učitelja s kolegama i upravom škole u većoj mjeri je zadovoljavajući, karakterizira ga prijateljstvo, susretljivost i briga za druge (4.2 / 46.4\%). Smatraju da je u obrazovnim pitanjima uvijek moguće dobiti kvalitetnu pomoć od svojih kolega (4.4 / 54\%), Većina učitelja u školama međusobno se podržava i pomaže (4.2 / 46.2\%). Prevladava mišljenje da im uprava škole pruža potporu (4.2 / 52\%) i da od nje mogu dobiti pomoć i savjet u obrazovnim pitanjima (4.2 / 51.4\%) te da njihov odnos sa školskom upravom ispunjen poštovanjem i povjerenjem (4.6 / 62.3\%), što je jako važno kako bi se učitelj osjećao ugodno i bez stresa se maksimalno posvetio radu s djecom.

Kolektivna školska kultura: Rezultati ovog istraživanja pokazali su da velik broj učitelja i školskih uprava imaju zajedničke ciljeve prema kojima bi se škola trebala razvijati (4.2 / 48.2\%) i pogled na način razvoja škole (4.0 / 41.1\%) te da za svih vrijedi isti skup normi i pravila ponašanja (4.0 / 40.1\%). Sve dok je većina učitelja 'pozitivno' orijentirana, školama je lakše raditi na njihovom poboljšanju i razvoju.

Samoučinkovitost učitelja: Svakom, a posebno učiteljima, mišljenje o samom sebi kao i svojoj samoučinkovitosti jako je važno. Učitelji drže da dobro rade svoj posao (5,0 / 81.8\%), zadovoljni su svojim poučavanjem (4.9 / 76.8\%) i smatraju da su uspješni u tome (4.4 / 49.6\%), pa rezultate svog poučavanja vide svaki dan (4.4 / 49.0). Vjeruju i da obavljaju važan posao (4.9 / 71.3\%). Za učitelja je to jako važno jer zadovoljan učitelj vjeruje u sebe i ulaže više truda u pripremu svog rada i njegovanje odnosa sa svojim učenicima.

Autonomija učitelja: $U$ procjeni vlastite autonomije u radu učitelji su nešto suzdržaniji iako, u usporedbi s učiteljima drugih predmeta, spadaju među one s najvećom autonomijom. Posljedica je to naglih promjena $\mathrm{u}$ informatičkom i tehnološkom području koje nisu promptno praćene kurikulumom i udžbenicima. Iznimno, u ovoj kategoriji pitanja koristila se Likertova skala s 5 vrijednosti. Najveću autonomiju imaju u prilagođavanju nastavnih materijala kako bi učenici realizirali obrazovne ishode (4.0 / 72.8\%). Prilagođavaju brzinu napredovanja u procesu poučavanja sposobnostima učenika (3.6 / 54.1\%). Kada je u pitanju izmjena predmetnog kurikula 
kako bi uključili neplanirane događaje ili situacije (3.4 / 47.3\%) te rad na područjima ili temama koje nisu uključene u predmetnom kurikulumu / planu (3.3 / 42.2\%), najveći broj učitelja smatra kako imaju tek određenu slobodu odlučivanja. Osjećaju veću autonomiju u izboru načina ophođenja prema učenicima koji sami smatraju najboljim za učenikovo učenje i razvoj (3.7 / 64.1\%). Isto vrijedi i za postavljanje realnih ciljeva za svakog učenika (3.6 / $58.8 \%)$.

Zadovoljstvo učiteljskim zanimanjem: Većina je učitelja izjavila da uživa raditi kao učitelj (4.9 / 73\%) i da se raduje odlasku u školu svaki dan (4.4 / 56.6\%). Međutim, njihovo suglasje s tvrdnjom da je učiteljski poziv jako isplativ bilo je izrazito nisko (2.5 / 12.1\%). U naknadnim komentarima na provedenu anketu neki su učitelji izjavili da nisu razumjeli što se misli pod pojmom isplativosti, mnogi su nadopunili svoj odgovor objašnjenjem da ako se misli na financijsku dobit tada oni svakako nisu zadovoljni. Može se zaključiti da učiteljsko zanimanje jest lijepo, ali vrijednost rada nije odgovarajuće vrednovana kroz učiteljsku plaću. Unatoč tome, mnogi se svako jutro bude radujući se odlasku na posao (4.1 / 45.9\%).

Motivacija za napuštanje učiteljskog zanimanja: Relativno mali broj učitelja želio bi imati drugi posao (2.8 / 20.2\%). Slično, ako bi bili u situaciji ponovnog izbora zanimanja, uz sve probleme i moguće nedostatke učiteljskog zanimanja, malo je učitelja koji ne bi opet odabrali to zanimanje (2.6 / 17.0\%). Relativno mali broj učitelja često razmišlja o napuštanju učiteljske profesije (2.3 / 13.1\%). Zbog iskustva s online nastavom u doba pandemije COVID19 znatan broj učitelja intenzivirao je ta razmišljanja (2.57 / 20\%), a nekoliko je učitelja u komentaru najavilo da će promijeniti zanimanje ako se slična situacija ponovi.

Društveni status: Pitanje društvenog statusa jedan je od najvećih problema učitelja u Republici Hrvatskoj. Vrlo su rijetki učitelji koji osjećaju zavist kod sugovornika kada se u novom društvu predstave kao učitelj / nastavnik (2.5 / 8.4\%). Kada su u pitanju roditelji, učitelji u podijeljenih stavova o tome da li ih uvažavaju i poštuju ako se susretnu na javnom mjestu (3.9 / 25.4\%). Također, isti stavovi vrijede i za susrete s roditeljima na satu informacija u školi (4.0 / 25.2\%). Međutim, poražavajući su rezultati koji se odnosi na to kako javnost razumije radno opterećenje učitelja tijekom nastavnih i nenastavnih dana (1.7 / 1.8\%), a povlačenje po medijima ružnih vijesti o neradu ili lošem ponašanju učitelja je poprilično demotivirajuće za daljnji rad.

Pritisak na samostalnost učitelja: Prateći medije često slušamo o problemima koje učitelji imaju jer su previše izloženi različitim pritiscima u svom radu i to od strane roditelja, stručne službe i ravnatelja. Roditelji često znaju biti zaštitnički orijentirani prema svojoj djeci pa znaju preći dopuštene mjere intervencije. Većina je učitelja zadovoljna radom stručne službe, smatraju da ih uvijek podržava i ne preispituje njihove ocjene (4.6 / 42.5\%). Učitelji su najzadovoljniji sa svojim ravnateljima, za koje smatraju da ne kontroliraju njihove odluke prilikom zaključivanja ocjena (5.0 / 48.8\%). Ipak, postoje i nastavnici koji osjećaju veliki pritisak roditelja (18.4\%), stručnih službi $(9.0 \%)$ i ravnatelja (6.8\%).

Opterećenja učitelja u online nastavi: Rezultati su pokazali da je učiteljima prijelaz na online oblik poučavanja zahtijevao značajno više vremena za pripremu nastavnih materijala nego inače (5.5 / $87.7 \%$ ). Mnogi su se učitelji našli u novim situacijama rada s informacijsko-komunikacijskom tehnologijom s kojom možda nisu bili dovoljno ili uopće upoznati. Izrada primjerenih materijala za ovaj oblik nastave predstavljala je izazov za mnoge od njih. Veći broj učitelja izjavio je da su tijekom pandemije bili stalno dostupni i nisu imali vremena za dnevni odmor (5.4 / $87.1 \%$ ). Način rada je bio organiziran na razini države, s malim odstupanjima specifičnim za svaku školu, tako da mnogi učitelji, pogotovo oni koji su predavali više predmeta, nisu imali dovoljno vremena za svoje osobne i obiteljske obveze. Većina je učitelja osjećala stres zbog učenika koji nisu sudjelovali u školskim aktivnostima (5.0 / 72.6\%). Uzimajući u obzir uloženi trud i rad, te cjelodnevnu dostupnost, ne iznenađuje novonastali stres zbog nemarnih učenika.

\subsection{Utjecaj osobnih karakteristika učitelja na njihove stavove}

Spol: Žene u većoj mjeri smatraju da su pretrpane poslom ( $p=0.049)$, češće rade pripreme van redovnog radnog vremena $(p=0.010)$, žele više zajedničkog vremena s učenicima (0.007), zbog online nastave izraženiji im je osjećaj da ne postoji vrijeme za dnevni odmor $(p=0.005)$ kao i stres zbog učenika koji ne sudjeluju u školskim aktivnostima $(p=0.000)$.

Muškarci općenito imaju bolji odnos s upravom škole koji karakterizira poštovanje i povjerenje $(p=0.022)$ te od uprave uvijek mogu dobiti pomoć i savjet $(p=0.026)$. Veći broj učitelja, da mogu ponovo birati, nikada ne bi izabrali učiteljsku profesiju $(p=0.005)$.

Škola u kojoj rade: Učitelji u osnovnoj školi imaju bolje mišljenje o prijateljskom odnosu ispunjenom poštovanjem među kolegama $(p=0.009)$ koji pomažu jedni drugima $(p=0.020)$ i primjenjuju zajedničke norme i pravila ponašanja $(p=0.000)$. Zadovoljniji su svojim poučavanjem ( $p=0.048$ ) i svaki dan vide veće pozitivne rezultate svoga poučavanja $(p=0.014)$.

Nastavnici iz srednjih škola pripreme za nastavu češće rade izvan radnog vremena $(p=0.001)$ i smatraju posao u školi stresnim, bez vremena za oporavak $(p=0.031)$. Teže motiviraju učenike $(p=0.000)$ i učenici 
im ulažu manje truda ( $p=0.014)$. Na satu informacija $s$ roditeljima osjećaju veće poštovanje $(p=0.038)$, a roditelji im rjeđe traže veće ocjene za svoje dijete.

Završeni studij: Pomalo iznenađujuće, ovaj čimbenik ukazuje na najmanje razlika. Učiteljima koji nisu završili nastavnički studij već su pedagoške kompetencije stekli nakon završetka nekog drugog, pretežno inženjerskog studija, priprema nastavnih materijala oduzima im više vremena nego onima koji su završili nastavnički studij $(p=0.040)$, a roditelji na satu informacija rjeđe od njih traže veće ocjene za dijete $(p=0.047)$. lako statistički nisu značajne razlike, uočava se da učitelji koji nisu završili nastavnički studij se češće pripremaju za nastavu van osmosatnog radnog vremena $(p=0.057)$ i ne bi ponovo izabrali učiteljski posao ( $p=0.075)$.

Radno iskustvo u obrazovanju: Učitelji početnici do 5 godina staža drže u većoj mjeri da u njihovoj školi učitelji pomažu jedni drugima $(p=0.006)$ i da sami mogu uvijek dobiti kvalitetnu pomoć kolega $(p=0.006)$ i uprave škole $(p=0.000) s$ kojom odnos karakterizira poštovanje i povjerenje $(p=0.000)$. Upravu škole smatraju korisnom $(p=0.000)$ i međusobno dijele zajedničke ciljeve $(p=0.024)$ i način razvoja škole $(p=0.035)$ uz primjenu zajedničkih normi i pravila ponašanja ( $P=0.001)$. Najviše uživaju raditi kao učitelji $(p=0.010)$, raduju se odlasku na posao svako jutro $(p=0.000)$ i osjećaju se kao da obavljaju važan posao $(p=0.031)$ kojeg ne bi mijenjali $(p=0.004)$ i ponovo bi ga izabrali $(p=0.000)$. Iskustvo $s$ online nastavom nije ih potaklo na intenzivnije razmišljanje o napuštanju učiteljske profesije $(p=0.002)$. Zajedno s učiteljima koji imaju 6-15 godina staža više osjećaju zavist društva zbog posla kojim se bave.

Učitelji koji imaju 6-15 godina staža i prije pandemije $(p=0.002)$ i za vrijeme pandemije $(p=0.002)$ najviše su od svih razmišljali o promjeni profesije. Zbog online nastave imaju izraženiji osjećaj da su stalno dostupni ( $p=0.031$ ) i osjećaju veći stres zbog učenika koji ne sudjeluju u školskim aktivnostima $(p=0.000)$. Zajedno s učiteljima koji imaju 16-30 godina staža, više su pretrpani poslom $(p=0.001)$ i doživljavaju posao ubrzanim i stresnim, bez vremena za oporavak $(p=0.000)$.

Učitelji s 16-40 godina staža u obrazovanju ne osjećaju zavist u društvu zbog posla kojim se bave $(p=0.049)$.

Učitelji s više od 30 godina iskustva u obrazovanju imaju najmanju potrebu zajedničkog vremena $s$ učenicima $(p=0.006)$, najmanje očekuju pomoć od kolega $(p=0.006)$ i najmanje se raduju odlasku u školu $(p=0.000)$. Najviše bi željeli imati drugi posao a ne posao učitelja $(p=0.004)$ kojeg ne bi ponovo izabrali $(p=0.002)$.

Završeni studij: Pomalo iznenađujuće, ovaj čimbenik ukazuje na najmanje razlika. Učiteljima koji nisu završili nastavnički studij već su pedagoške kompetencije stekli nakon završetka nekog drugog, pretežno inženjerskog studija, priprema nastavnih materijala oduzima im više vremena nego onima koji su završili nastavnički studij $(p=0.040)$, a roditelji na satu informacija rjeđe od njih traže veće ocjene za dijete $(p=0.047)$. lako statistički nisu značajne razlike, uočava se da se učitelji koji nisu završili nastavnički studij češće pripremaju za nastavu van osmosatnog radnog vremena $(p=0.057)$ i da ne bi ponovo izabrali učiteljski posao $(p=0.075)$.

Napredovanje u učiteljskom zvanju: Učitelji koji nisu birani u više zvanje, a nisu ni voditelji županijskih vijeća ili članovi stručnih skupina, teže uspijevaju zainteresirati učenike za ozbiljniji rad u školi ( $p=0.002)$, imaju pozitivniji stav o odnosima među kolegama $(p=0.028)$, manje osjećaju uvažavanje i poštovanje roditelja na satu informacija $(p=0.008)$ i kad ih sretnu na javnom mjestu $(p=0.005)$, a imaju najmanju autonomiju u prilagodbi nastavnih materijala kako bi učenici postigli obrazovne ishode $(p=0.030)$.

Učitelji u zvanju mentora češće od ostalih pripremaju se za nastavu van osmosatnog radnog vremena $(p=0.045)$ i osjećaju veći stres zbog ubrzanog života $u$ školi $(p=0.046)$ te smatraju da su pretrpani poslom ( $p=0.047)$. Najviše se raduju odlasku u školu $(p=0.025)$ te imaju najveću autonomiju kod rada $s$ temama koje nisu uključene u predmetnom kurikulu $(p=0.028)$. Zajedno s učiteljima u zvanju savjetnika najviše uživaju raditi kao učitelji $(p=0.004)$ i najuvjereniji su u uspješnost svoga poučavanja $(p=0.002)$.

Učitelji savjetnici najzadovoljniji su svojim poučavanjem, a iskustva online nastave najmanje su ih potaknula za razmišljanje o napuštanju učiteljskog posla $(p=0.029)$. Imaju najviše autonomije $u$ ophođenju prema učenicima na način kojeg smatraju najboljim za njihovo učenje i razvoj ( $p=0.042)$.

\subsection{Faktorska analiza - ispitivanje sadržajne valjanosti}

Provedena je eksploratorna faktorska analiza kako bi se provjerila povezanost pitanja unutar samih kategorija, eventualno potvrdilo grupiranje pojedinih pitanja u kategorije te istovremeno provjerila kontekstualna valjanost instrumenta. Faktorska analiza provedena je i na cijelom skupu od 2429 učitelja svih predmeta (budući nije rađena imputacija za 420 zapisa kod kojih nisu bile popunjene naknadno dodane kategorije) i na podskupu 332 učitelja informatike, tehničke kulture i srodnih strukovnih predmeta. Pouzdanost, odnosno unutarnja povezanost upitnika je 0.806 i 0.834 respektivno (Cronbachov Alpha) pa se upitnik može smatrati pouzdanim. Visoka vrijednost Kaiser-Meyer-Olkin mjere prikladnosti uzorka (KMO=0.914 i 0.892, 
Bartlett $p=0.000$ ) potvrdila je primjerenost uporabe faktorske analize. Nadalje, zbog većeg broja promatranih varijabli s obzirom na broj pitanja (>30:1) te većeg uzorka ( $\mathrm{N}=2429)$, promatrala se i srednja vrijednost temeljnog kontinuiteta svakog pitanja (eng. Communalities) koja iznosi 0.68375 odnosno 0.712 $(>0.6)$ što je također potvrdilo prikladnost primjene faktorske analize na odabranom uzorku (Cater \& Machtmes, 2008).

Odabrana je metoda ekstrakcije Principal Component Analysis (PCA), uz Varimax metodu rotacije $s$ Kaiserovom normalizacijom, čime smo dobili 10 jako dobro definiranih faktora. Većina koeficijenata u matrici rotiranih komponenti je veća od 0.8 , a samo jedan koji se odnosi na isplativost učiteljskog posla je graničnih 0.4 zbog nejasnog značenja „isplativosti“.

Tablica 3. prikazuje strukturu upitnika prema kategorijama, mjeru unutarnje povezanosti (pouzdanosti - Conbach alpha) pitanja unutar svake kategorije za sve ispitanike, samo za I-TK-strukovne učitelje i iz Skaalvikova istraživanja. Navedeno je i korigirano grupiranje pitanja u kategorije na temelju provedene faktorske analize te pripadajući postotak varijance kojeg faktori objašnjavaju za sve učitelje i ITK-strukovne učitelje.

Kao tri najsnažnija faktora kada se analiziraju svi učitelji izdvojeni su: Kolektivna školska kultura $i$ suradnja s kolegama i upravom škole (13,988\% varijance), Zadovoljstvo učiteljskim zanimanjem $i$ motivacija za napuštanje učiteljskog zanimanja (10,210\% varijance) te Autonomija rada učitelja $(8,710 \%$ varijance. Kada se promotre najvažniji faktori za učitelje informatike, tehničke kulture i strukovnih predmeta uočava se sitna razlika u odnosu na sve učitelje. I dalje je najznačajniji Kolektivna školska kultura i suradnja s kolegama i upravom škole (15.081), ali sada je Autonomija rada učitelja (9.490) neznatno utjecajnija od faktora Zadovoljstvo učiteljskim zanimanjem i motivacija za napuštanjem učiteljskog zanimanja (9,439\% varijance).

\begin{tabular}{|c|c|c|c|c|c|c|}
\hline \multirow{2}{*}{ Kategorija pitanja } & \multirow{2}{*}{$\begin{array}{c}\text { Broj } \\
\text { pitanja }\end{array}$} & \multicolumn{3}{|c|}{$\begin{array}{l}\text { Unutarnja povezanost } \\
\text { (pouzdanost) }\end{array}$} & \multicolumn{2}{|c|}{ Faktori - \% varijance } \\
\hline & & $\begin{array}{c}\text { Svi } \\
\text { učitelji }\end{array}$ & $\begin{array}{l}\text { I-TK- } \\
\text { Strukovni }\end{array}$ & $\begin{array}{l}\text { Skaalvik } \\
2018 .\end{array}$ & Svi učitelji & I-TK-Strukovni \\
\hline $\begin{array}{l}\text { Rješavanje disciplinskih } \\
\text { problema u radu s } \\
\text { učenicima }\end{array}$ & 2 & 0.847 & 0.847 & 0.87 & $F 10-3.5 \%$ & F10 - 3.4\% \\
\hline Nedostatak vremena & 5 & 0.813 & 0.814 & 0.83 & $F 6-6.2 \%$ & $F 6-6.5 \%$ \\
\hline $\begin{array}{l}\text { Motivacija učenika za } \\
\text { učenja }\end{array}$ & 4 & 0.896 & 0.911 & 0.89 & $F 4-6.5$ & $\mathrm{~F} 4-7.1 \%$ \\
\hline $\begin{array}{l}\text { Odnosi s kolegama i } \\
\text { upravom škole }\end{array}$ & 6 & 0.929 & 0.931 & 0.86 & \multirow{2}{*}{$\begin{array}{c}\mathrm{F} 1-14,0 \% \\
\text { Povezanost } \\
0.949\end{array}$} & \multirow{2}{*}{$\begin{array}{c}\mathrm{F} 1-15.1 \% \\
\text { Povezanost } \\
0.951\end{array}$} \\
\hline Kolektivna školska kultura & 3 & 0.906 & 0.913 & 0.78 & & \\
\hline Samoučinkovitost učitelja & 5 & 0.825 & 0.832 & 0.88 & F5 - $6.5 \%$ & F5 - 6.9\% \\
\hline Autonomija učitelja & 6 & 0.868 & 0.923 & 0.85 & F3 - 8,7\% & $F 2-9.5 \%$ \\
\hline $\begin{array}{l}\text { Zadovoljstvo učiteljskim } \\
\text { zanimanjem }\end{array}$ & 4 & 0.869 & 0.866 & 0.90 & \multirow{2}{*}{$\begin{array}{c}\mathrm{F} 2-10,2 \% \\
\text { Povezanost } \\
0.908\end{array}$} & \multirow{2}{*}{$\begin{array}{c}\mathrm{F} 3-9.4 \% \\
\text { Povezanost } \\
0.900\end{array}$} \\
\hline $\begin{array}{l}\text { Motivacija za napuštanje } \\
\text { učiteljskog zanimanja }\end{array}$ & 4 & 0.876 & 0.860 & 0.90 & & \\
\hline Društveni status* & 4 & 0.705 & 0.749 & & $F 8-4.2 \%$ & $F 7-4.7 \%$ \\
\hline $\begin{array}{l}\text { Pritisak na samostalnost } \\
\text { učitelja* }\end{array}$ & 3 & 0.705 & 0.734 & & $F 7-4.4 \%$ & $F 8-4.4 \%$ \\
\hline $\begin{array}{l}\text { Opterećenje učitelja u } \\
\text { online nastavi }^{*}\end{array}$ & 3 & 0.723 & 0.759 & & $\mathrm{~F} 9-4.1 \%$ & $\mathrm{~F} 9-4.4 \%$ \\
\hline
\end{tabular}

Tablica 3. Rezultati faktorske analize - kontekstualna valjanost 
Pitanja iz kategorija Odnosi s kolegama i upravom škole te Kolektivna školska kultura pokazala su veliku i unutarnju i međusobnu unutarnju povezanost. Pitanja ovih dviju kategorija imaju zajedničku strukturu te bi njihovo povezivanje u jednu kategoriju $\mathrm{s}$ nazivom Kolektivna školska kultura i suradnja s kolegama $i$ upravom škole bilo primjerenije. Provjera navedene tvrdnje provedena je zasebnom faktorskom analizom nad promatranim kategorijama. Analiza je istaknula postojanje samo jednog faktora unutarnje povezanosti 0.949 / 0.951.

Slična situacija dogodila se i s pitanjima iz kategorija Zadovoljstvo učiteljskim zanimanjem i Motivacija za napuštanjem učiteljskog zanimanja gdje je unutarnja povezanost jedinstvenog faktora 0.908 / 0.90. Zanimljivo, sva pitanja kategorije Zadovoljstvo učiteljskim zanimanjem imala su visoka, ali pozitivna opterećenja (eng. Factor loadings), dok su sva pitanja kategorije Motivacija za napuštanjem učiteljskog zanimanja iskazala visoka, ali negativna opterećenja. Može se zaključiti da dvije promatrane kategorije imaju istu strukturu i mogu se povezati u jednu kategoriju. Različiti predznaci promatranih kategorija znače da će motivacija za napuštanje učiteljskog zanimanja slabiti s povećanjem općeg zadovoljstva učiteljskim zanimanjem.

Rezultati faktorske analize potvrdili su povezanost pitanja i u ostalim kategorijama. Kategorije pitanja koje nisu preuzete iz Skaalvikova istraživanja (2017): opterećenje učitelja u online nastavi (0.723 i 0.759), pritisak na samostalnost učitelja (0.705 i 0.734) i društveni status (0.705 i 0.749 ) pokazale su nešto slabiju povezanost.

Kontekstualna valjanost u oba slučaja potvrđuje da se sva pitanja unutar neke kategorije odnose na zajednički faktor, što govori u prilog sadržajne valjanosti istraživanja. Izlučeni faktori i njihova struktura manifestnih varijabli sukladni su sa Skaalvikovim istraživanjem, a jedino odstupanje primjećuju se u manjem broju faktora u ovom istraživanju jer je u dva navrata došlo do povezivanja po dvije srodne kategorija u jednu.

\subsection{Kvalitativna analiza komentara ispitanika}

Posljednja rubrika u istraživanju je pružila mogućnost ostavljanja komentara o istraživanoj problematici i samoj anketi. Od 2829 ispitanika 462 učitelja je ostavilo osobne komentare koji su grupirani u nekoliko kategorija prema zajedničkim obilježjima. Komentari učitelja informatike, tehničke kulture i strukovnih predmeta označeni su znakom „*“.

\section{Zanemarivanja od strane Ministarstva i podilaženje roditeljima}

-„Odnos Ministarstva prema radu učitelja / nastavnika / stručnih suradnika je posljednjih nekoliko godina katastrofalan, ali za vrijeme koronavirusa $i$ nastave na daljinu (+ malo poslije toga) - potpuno ponižavanje. Loomen $i$ slično je za moj pojam "platforme za cjeloživotno obrazovanje" na granici vrijeđanja inteligencije;

- „Osjećam se šikanirano od našeg ministarstva koje nas ponižava kao da smo neodgojeni, lopovi $i$ lažovi" *

- „Ja imam dojam da smo svima za sve krivi jer su učenici i roditelji dobili podršku Ministarstva da nas maltretiraju...a da ne govorim o anonimnim prijavama koje su često neutemeljene, ali to nikoga ne sprečava da nam zagorčava život"

- „Za vrijeme korona virusa, MZO se je obraćalo učiteljima preko medija i preko roditelja npr. izdalo je naputke za vrednovanje učenika za vrijeme online nastave tako da ih je objavilo na svom webu, a ne tako da su dopis poslali u škole i da su škole obavještavale roditelje. Takvih primjera ima još npr. organizacija izleta, komunikacija MZO-a nedostaje."

- „Žao mi je što anketa nije obuhvatila pitanja o kvaliteti i dostupnosti sustava Carnet (Loomen, Carnet Webmail, Skype za tvrtke), koji je godinama preslabe kvalitete u vršnim danima (upisi, svjedodžbe), a MZO ništa nije učinilo da bi ga kontroliralo i poboljšalo kvalitetu (sada kada smo svi ovisili o njima)."

\section{Dodatno opterećenje online nastavom}

- "Nikada prije u životu nisam imala osjećaj da radim toliko puno, s tako lošim rezultatima. Smatram da učenici nisu posvećeni nastavnim sadržajima koliko god malo ili puno vremena provodili za računalom $u$ online nastavi." *

- „Kao nastavnik strukovnih predmeta ne želim raditi online jer je to gubljenje vremena. Učenicima treba rad u učionici i kada je teorijska nastave struke $i$ kada je to praktična nastava." *

- „A za pandemiju mogu reći: 'Jedva čekam da se vratim u školu', a i neki moji učenici s kojima sam komunicirala o tome!" *

- „Online nastava je nužno zlo, morali smo ju proći zbog specifične situacije, no u medijima se o njoj govori (pogotovo od strane ministrice) kao da je revolucionaran oblik nastave koji bi se mogao zadržati jer njemu ništa ne nedostaje. Ovih par mjeseci online nastave bila je noćna mora, s cjelodnevnim radnim danom od 6 ujutro do 10 navečer, a percepcija javnosti je da smo se ionako doma odmarali. Da se ovakav oblik nastave nastavi, sumnjam da bih ostala u školi jer bez interakcije i komunikacije ovo nije prava škola." 
- „Zaboravili ste pitati koliki pritisak osjećamo zbog zanemarivanja vlastite djece zbog ovog posla, pogotovo u online nastavi, i od ostalih ukućana koji uopće ne shvaćaju koliko nas je 'satrala' online nastava i odgovornost za neaktivnu djecu i ogroman bezobrazluk roditelja koji nikakve granice nemaju!"

- „Kao i u svim poslovima, posao nastavnika ima uspona $i$ padova. Najviše me u poslu smeta preispitivanje mog načina rada i ocjena od strane ljudi koji za to nisu kompetentni (roditelji i stručna služba). Smeta me i što ne postoji vrednovanje rada nastavnika pa nastavnici koji rade svoj posao dobro i u skladu s metodologijom primjerenom današnjem dobu, redovito se educiraju i razvijaju, prolaze lošije od nastavnika koji ne rade ništa doli traže od učenika da prepisuju iz udžbenika."

- "Ne razumijem negativan stav koji se proširio o online nastavi, pa to je odlična stvar, svugdje u svijetu postoji mogućnost za remote working i mi trebamo djecu pripremiti za to. Mogao bih ovako do mirovine, da ne moram 'visiti' po sjednicama, vijećima, sastancima, biti stalno okružen bukom, već raditi $u$ pidžami uz kavicu. I najvažnija stvar, nemojmo zaboraviti da nam je online nastava sačuvala plaće. Cijelo vrijeme smo imali podršku i svaka čast na organizaciji u ovako kratkom vremenu."

- "Škola na daljinu je pokazala sve slabosti "Škole za život", nesposobnost naših učenika da sami išta nauče, čak $i$ iz desetorostruko smanjenih sadržaja, štoviše, većinom nisu u stanju pažljivo pročitati upute. Jedina je korist što su uvidjeli da nove nastavne metode, tzv. projektne nastave, nisu rješenje za njihovo neznanje i posvemašnju neorganiziranost $u$ obilju vremena. I ponajbolji su učenici postupno izgubili motivaciju. ,

\section{Pritisak roditelja}

-„Sva nepravda s kojom se učitelji dnevno susreću, na žalost, ne stane u jednu anketu. Od roditelja koji su me nazivali pogrdnim imenima, 'žicali' ocjene i prijetili inspekcijom, omalovažavanja čak i od strane njihove djece, nebrojenih zamjena na kojima glumim kviska $i$ karticu za sve, dovođenja u pitanje mojih stručnih znanja i vještina nakon ne znam koliko položenih ispita u životu... odaberite jedno od navedenog i već je previše za cijeli jedan radni vijek. A imam tek pet godina radnog iskustva. Štošta još nisam navela. Jesam li motivirana za rad? Na žalost - jesam. U tome i jest problem."

-„I 'u koroni' i prije nastave na daljinu prigovori roditelja, učenika i ravnatelja (točno ovim redom) idu ponajprije prema kolegama koji savjesno i marljivo rade; oni koji "šlepaju" iste materijale desetljećima nitko ništa ne pita. Zašto? Jer Ministarstvo daje roditeljima za (pre)veliko pravo biti pametniji od ikog."
-,Mislim da je posebno opterećujući posljednji mjesec nastave kada smo često izloženi različitim pritiscima od strane učenika i roditelja. Ove školske godine je to posebno prisutno te sam primila nekoliko poruka i mailova sa željom podizanja zaključne ocjene učenika 7. i 8.razreda zbog visokih bodovnih pragova $i$ velike konkurencije pri upisu u gimnazije u gradu Zagrebu."

-„U jednom trenutku zbog slabog odziva učenika $i$ roditelja, sve bih ostavila. $U$ drugom, opet imate $i$ učenika koji žele znati i roditelja koji prihvaćaju sugestije, traže pomoć. Tada vidim svrhu svoga rada $i$ osjećam zadovoljstvo zbog toga." *

\section{Pozitivan stav i očekivanja od ankete}

- „Prepoznati stvarni problemi učiteljskog zanimanja."

- „Čini se da je anketu radio netko tko shvaća koja su opterećenja nastavnika u nastavi i s kojim se problemima susreće, to je dosta rijetko pa pohvaljujem autore / ice."

- „Rijetko koja anketa je ovako dobro pokrila sva bitna pitanja ovog posla" *

- „Odlična, postavljena prava pitanja koja zadiru u srž stvarnosti bez uljepšavanja" *

-„Zahvaljujem na anketi koja mi daje osjećaj nade da netko ipak propituje i brine o nama učiteljima $u$ novim društvenim promjenama."

-„Nadam se da će rezultati ankete potaknuti relevantne institucije na dijalog s nastavnicima kao odgovornim osobama oko svih oblika reformi, tj. promjena u obrazovanju. Nastavnici su ipak ti koji promjene i provode."

-„Zanimljiva anketa koji bi trebala služiti MZO kako bi pokušali nešto promijeniti u sustavu obrazovanja!"

\section{Prijedlozi za proširenje ankete}

-„Ovoj anketi nedostaju, po mom mišljenju, važni upiti $u$ vezi sa sveprisutnim $i$ očitim varanjem $u$ bilo kojem obliku provjere (domaće zadaće, tzv. projekti, pisane provjere na daljinu), čak i kod usmenih odgovora na daljinu s nazočnošću druge osobe (instruktora) $u$ istoj prostoriji, koje izvjesno potiču ambiciozni roditelji i djeca nezainteresirana za bilo kakav oblik učenja.

-„Nedostaju pitanja vezana za učenike $s$ poteškoćama...."

-„Nema pitanja koja se odnose na komunikaciju MZO prema učiteljima."

- "Žao mi je što u anketi niste dotaknuli pitanje motiviranosti za napredovanje nastavnika, koje ima velike veze s motiviranošću za nastavu. Mislim da je ovaj način napredovanja za mnoge nastavnike velika zamka. Mnogi od njih, u silnoj želji za napredovanjem, postaju 'lovci na bodove', zbog čega im sama nastava pada u drugi plan, a zanimaju ih samo projekti. Pri 
njihovoj provedbi nastava se odrađuje loše ili nikako, ali to postaje nebitno." *

-„Bilo bi interesantno vidjeti anketu $i$ mišljenje učitelja a pogotovo ravnatelja o činjenici da se $u$ školama neradnicima ne može stati u kraj. Isto tako ne postoji sustav nagrađivanja učinkovitijih učitelja za njihov dodatni angažman."

\section{Zaključak}

Uz svu ljubav prema poslu kojeg većina učitelja smatra pozivom, istraživanje je pokazalo i njegovu tamniju stranu.

Tri četvrtine učitelja uživa u svom radu iako svoj posao smatra vrlo neisplativim, zadovoljno je kvalitetom svoga poučavanja i smatra da obavljaju važan posao. Ipak, svaki peti učitelj želi imati drugi posao i ne bi ga ponovo izabrao. Učitelji su pretrpani poslom, pripreme obavljaju često $\mathrm{i}$ van radnog vremena, administrativni poslovi ih puno opterećuju, ali su svjesni da javnost uopće ne razumije njihovo radno opterećenje tijekom nastavnih i nenastavnih dana. Gotovo ih polovina nije zadovoljna motivacijom i zalaganjem učenika. Suradnjom i podrškom kolega i uprave te kolektivnom školskom kulturom dvostruko je više zadovoljnih nego nezadovoljnih učitelja. Imaju veliku autonomiju u prilagodbi nastavnih materijala i načina ophođenja prema učenicima.

Društveni status im je srozan, nitko im u društvu ne zavidi, tek četvrtina ih je zadovoljna poštivanjem od strane roditelja. Petina učitelja smatra da roditelji prelaze dopuštenu razinu intervenirajući radi veće ocjene za svoje dijete, za što u manjoj mjeri imaju podršku stručnih službi i ravnatelja. Značajnim izvorom stresa pokazali su se iznuđena online nastava koja ionako preopterećenim nastavnicima traži dodatno vrijeme za pripremu nastavnih materijala, osjećaj cjelodnevne dostupnosti unatoč frustraciji zbog nesudjelovanja dijela učenika u školskim aktivnostima, izostanak dnevnog odmora i nedostatak vremena za osobne i obiteljske obveze.

Potvrđeno je da žene imaju veći vremenski pritisak i fizičku i emocionalnu iscrpljenost, čemu pridonose i veće odgovornosti kod kuće. Premda se ne razlikuju u osjećaju zadovoljstva učiteljskim poslom i imaju bolji odnos s upravom, muškarci su skloniji napuštanju posla i ne bi ponovo izabrali učiteljski posao.

Učitelji u osnovnoj školi pozitivnije doživljavaju odnos s kolegama i njihovu spremnost za pomoć i zadovoljniji su svojim poučavanje, a imaju manje poštivanje roditelja. Nastavnici u srednjim školama češće se pripremaju za nastavu van radnog vremena, a posao u školi im je stresniji.

Učitelji koji nisu završili nastavnički studij troše više vremena na pripremu nastavnih materijala i više žale radi izbora učiteljskog posla.
Učitelji početnici imaju najpozitivniji stav prema gotovo svim varijablama koje se tiču školskog konteksta. Oni s 6-15 godina iskustva najskloniji su promjeni zanimanja, najteže im pada online nastava, a skupa s onima s 16-30 godina iskustva pretrpaniji su poslom i nemaju vremena za opravak. Oni iskusniji, s preko 30 godina iskustva u obrazovanju ne bi ponovo izabrali posao učitelja i žele drugi posao, ne osjećaju zavist u društvu zbog svoga posla, manje od ostalih očekuju pomoć od kolega i manje se raduju odlasku u školu.

Učitelji koji nisu napredovali u zvanju imaju najviše problema s motivacijom učenika i najmanju autonomiju u prilagodbi nastavnih materijala učeničkim karakteristikama, roditelji ih manje poštuju, a o odnosu s kolegama imaju pozitivniji stav. Mentori najviše od svih osjećaju da su pretrpani poslom, ali se najviše raduju odlasku u školu i zajedno sa savjetnicima najviše uživaju u svom poslu te su najuvjereniji u uspješnost svoga poučavanja. Savjetnici imaju najviše autonomije u izboru načina ophođenja prema učenicima, a iskustva online nastave najmanje su ih potakla na razmišljanje o promjeni profesije.

Iz slobodnih komentara učitelja mogu se nazrijeti novi stresori, prije svega nezadovoljstvo ponižavajućim odnosom i komunikacijom Ministarstva prema učiteljima, povlaštenim položajem roditelja koje im Ministarstvo osigurava, neosiguravanjem odgovarajuće infrastrukture za provođenje online nastave, neadekvatnim sustavom nagrađivanja nastavnika i izostankom sankcija za "neradnike“. Iznenađenje predstavlja to da su samo dva učitelja spomenula materijalni status učitelja kao problem, (,imam skoro duplo manju plaću od svog supruga koji radi duplo manje od mene") pogotovo što je u istoj školskoj godini trajao štrajk čiji glavni zahtjev je baš bio povećanje plaća.

Izuzetno je pozitivna percepcija učitelja o anketi korištenoj u ovom istraživanju za koju kažu da je pokrila sva bitna pitanja učiteljskog posla bez uljepšavanja i da im daje osjećaj nade da netko ipak propituje i brine o učiteljima te da će rezultati potaknuti relevantne institucije na dijalog $s$ nastavnicima koji provode sve promjene $u$ obrazovanju. Ovakav stav i očekivanja učitelja koji su, premda iscrpljeni i puni gorčine, na kraju jedne iznimno traumatične školske godine smogli snage $i$ vremena sudjelovati u još jednoj u nizu anketa izaziva iskreno divljenje i bit će poticaj da se napravi detaljnija analiza i za učitelje drugih predmeta.

\section{Literatura}

Anastasiou, S., \& Papagianni, A. (2020). Parents', Teachers' and Principals' Views on Parental 
Involvement in Secondary Education Schools in Greece. Education scienses.

Beck, R. C. (2003). Motivacija: teorija i načela. Zagreb: Naklada Slap.

Boru, N. (2018). The Factors Affecting TeacherMotivation. International Journal of Instruction, str. 761-776.

Cater, M., \& Machtmes, K. (2008). Informed DecisionMaking in Exploratory Factor Analysis. Journal of Youth Developmenrt, Volume 3, Number 3.

Ho, S. K. (2015). The relationship between teacher stress and burnout in Hong Kong: positive humour and gender as moderators. Educational Psychology.

Klassen, R. M., \& Chiu, M. M. (2010). Effects on Teachers' Self-Efficacy and Job Satisfaction: Teacher Gender, Years of Experience, and Job Stress. Journal of Educational Psychology, 102, str. 741-756

Klassen, R. M., \& Chiu, M. M. (2011). The occupational commitment and intention to quit of practicing and pre-service teachers: Influence of self-efficacy, job stress, and teaching context. Contemporary Educational Psychology, 36, str. 114-129.

Kokkinos, C. M. (2007). Job stressors, personality and burnout in primary school teachers. British Journal of Educational Psychology, str. 77,229-243.

Mađarac, D. (2018). Pojavnost nastavničkog stresa u suvremenom odgojno-obrazovnom sustavu. Didaskalos God.2,br. 2.

Osman, D. J., \& Warner, J. R. (2020). Measuring teacher motivation: The missing link between professional development and practice. Teaching and Teacher Education $92: 103064$

Sargent, T., \& Hannum, E. (2005). Keeping Teachers Happy : Job Satisfaction among Primary School Teachers in Rural Northwest China. Comparative Education Review, 49, str. 173-204.

Skaalvik, E. M., \& Skaalvik, S. (2014). Teacher selfefficacy and perceived autonomy: Realtions with teacher engagement, job satisfaction, and emotional exhaustion. Psychological Reports: Employment Psychology \& Marketing, 114(1), str. 68-77.

Skaalvik, E. M., \& Skaalvik, S. (2015). Job Satisfaction, Stress and Coping Strategies in the Teaching Profession - What do Teachers Say? International Education Studies, 8(3), str. 181-192.
Skaalvik, E. M., \& Skaalvik, S. (2017). Still motivated to teach? A study of school context variables, stress and job satisfaction among teachers in senior high school. Soc Psychool Educ, str. 15-37.

Skaalvik, E. M., \& Skaalvik, S. (2018). Job demands and job resources as predictors of teacher motivation and well-being. Social Psychology of Education.

Vazquez-Cano, E., \& Holgueras-Gonzalez, A. I. (2019). Teacher stress factors and performance in high school in Ecuador. KJEP 16:2, str. 21-41.

\section{Motivation for work and burnout of teachers of Informatics, Technical Culture and vocational subjects}

\section{Abstract}

A survey was conducted on a sample of 2829 primary and secondary school teachers from all Croatian counties with the aim of revealing their perception of working conditions as potential stressors and their relationship to work motivation, burnout symptoms and intention to leave work. The survey examined teachers' attitudes motivated by Skaalvik's research. Factor analysis yielded very similar results. Questions were added about the workload of teachers in online teaching caused by the COVOD-19 pandemic, about the pressure on teacher independence by principals and parents, and about the social status of teachers. The paper emphasizes the analysis of results related to 504 teachers of informatics, technology education and related vocational subjects. Differences in attitudes were shown with regard to gender, years of service, and the level of school in which they are employed, the type of studies they completed and the promotion of teachers. Qualitative analysis of teachers 'comments revealed the main sources of dissatisfaction from the teachers' perspective, as well as support for such research and hope that the results will change the Ministry's attitude towards teachers.

Keywords: teacher motivation; teacher stress; teacher burnout; job satisfaction; job requirements. 